\title{
Expression of cytokine and apoptosis-related genes in bovine peripheral blood mononuclear cells stimulated with Brucella abortus recombinant proteins
}

\author{
Young Bin Im', Myunghwan Jung ${ }^{1}$, Min-Kyoung Shin', Suk Kim² and Han Sang Yoo ${ }^{1,3^{*}}$
}

\begin{abstract}
Brucellosis is a clinically and economically important disease. Therefore, eradication programs of the disease have been implemented in several countries. One hurdle in these programs is the detection of infected animals at the early stage. Although the protein antigens as diagnostic antigens have recently received attention, the exact mechanisms at the beginning of immune responses are not yet known. Therefore, genes encoding five B. abortus cellular proteins were cloned and the expressed recombinant proteins were purified. The expression of several cytokine genes (IL-1 $\beta$, IL-4, IL-6, IL-12p40, IFN- $\gamma$, TNF-a, and iNOS) was analyzed in bovine peripheral blood mononuclear cells (bPBMC) after stimulation with the recombinant proteins. Three apoptosis-related genes, Bax, BCl-2, and TLR4, were also included in the analysis to find out the adverse effects of the proteins to the cells. Each protein induced different patterns of cytokine expression depending on the stimulation time and antigen dose. Expression of IL-6, IL-12p40, and IFN- $\gamma$ was induced with all of the proteins while IL-1 $\beta, I L-4$, TNF- $a$, and iNOS gene expression was not. Expression of apoptosisrelated genes was not altered except TLR4. These results suggest that the cellular antigens of $B$. abortus induce both humoral and cellular immunity via the production of IL-6, IL-12p40, and IFN- $\gamma$ in bPBMC without exerting any adverse effects on the cells.
\end{abstract}

\section{Introduction}

Brucellosis is a highly contagious zoonosis caused by Gram-negative bacteria of the genus Brucella. This disease affects livestock, wild animals, and humans. Ten species of the genus Brucella have been identified based on antigen variation and primary hosts [1,2]. Brucellosis causes significant economic losses not only because it affects animal production (reduced milk production, abortion, delayed conception, and impaired fertility) but also because detection of the disease in a region or country causes enactment of international veterinary regulations as well as restrictions on animal movements and trade $[1,3]$. In addition, brucellosis in human can

\footnotetext{
*Correspondence: yoohs@snu.ac.kr

${ }^{3}$ Institute of Green-Bio Science and Technology, Seoul National

University, Pyeongchang 25354, South Korea

Full list of author information is available at the end of the article
}

be severely debilitating and remains an important public health concern $[1,4]$.

Most serological diagnostic methods for detecting Brucella infection use antibodies against common Brucella antigens [5]. O-polysaccharide (OPS), a well-known immunodominant epitope in smooth lipopolysaccharide (SLPS), is commonly used in serological tests for diagnosing brucellosis [6-9]. Recently, several cellular proteins of $B$. abortus have been considered new diagnostic antigens because traditional diagnostic methods using Brucella LPS have low specificity due to cross-reactivity with other relevant bacteria such as Yersinia enterocolitica O:9 $[10,11]$.

Brucella abortus is a facultative intracellular bacterial pathogen that can survive intracellular defenses and hamper the induction of host humoral immune responses [12]. These properties help preventing the serological diagnosis of $B$. abortus infection. Infection 
with $B$. abortus potently activates both the innate and adaptive immune system, leading to a proinflammatory response that favors the T-helper 1 (Th1) responses [13, 14]. Although both antibody- and cell-mediated immune responses can influence the course of Brucella infection, the latter is primarily responsible for the clearance of intracellular bacteria [15].

Brucella spp. have mechanism that prevent activation of the host innate immune system [16]. Invasion through the digestive tract does not elicit any inflammatory response including cytokine production from the host [17]. Therefore, Brucella spp. invade silently or unnoticed by the innate immune system of the host [18].

Cytokines are important for responses to infection. Much attention has thus been given to research on cytokine-mediated inflammatory reactions in cases of brucellosis. Previous studies have revealed that B. abortus can induce the production of proinflammatory cytokines such as tumor necrosis factor- $\alpha$ (TNF- $\alpha$ ), interleukin (IL) -6, IL-12 and IL-1 $\beta$ by a variety of cell types and in mice [19-23].

Understanding immune mechanisms is an important step for the development of new control measures including diagnostic antigen(s) since most of the antigens have been selected based on reaction with antibodies without considering the immune responses in the host [24-27]. However, the precious mechanisms of B. abortus infection including the possible apoptotic activities have not been revealed in the expression of cytokines and apoptosis-related genes, yet. Therefore, to understand the mechanism underlying the immune responses to $B$. abortus, bovine peripheral blood mononuclear cells (bPBMC) were treated with five well-known immunoreactive $B$. abortus cellular proteins. Cytokine production and the expression of genes associated with apoptosis were then analyzed as the first step of understanding in the induction of immune responses.

\section{Materials and methods}

\section{Cloning and expression of B. abortus genes}

Genes encoding outer membrane protein 28 (OMP28), malate dehydrogenase (mdh), elongation factor Ts (tsf), arginase (rocF), and metal-dependent hydrolase (0628) of $B$. abortus 544 were amplified by PCR (Table 1), cloned, and expressed with a cold shock expression vector (pCold ${ }^{\mathrm{TM}}$ TF DNA; Takara, Japan) in E. coli DH5 $\alpha$. Sequences of the primers used for this procedure are shown in Table 1. Nucleotide sequences of the genes were confirmed by sequencing using an automatic sequencer and dye-termination sequencing system.

\section{Purification of the recombinant proteins}

Five E. coli clones were cultured at $37{ }^{\circ} \mathrm{C}$ overnight in $100 \mathrm{~mL}$ of LB broth (Duchefa Biochemie, The Netherlands) with $10 \mu \mathrm{g}$ of ampicillin (Duchefa Biochemie, The Netherlands). Sixty milli liters of the cultures were used to inoculate $1 \mathrm{~L}$ of LB broth containing $100 \mu \mathrm{g}$ of ampicillin. After culturing with shaking at $220 \mathrm{rpm}$ for $3 \mathrm{~h}$ at $37{ }^{\circ} \mathrm{C}$, isopropyl $\beta$ - $D$-1-thiogalactopyranoside (IPTG; Amresco, USA) was added at a final concentration of $0.5 \mathrm{mM}$ and the culture was further incubated overnight at $37{ }^{\circ} \mathrm{C}$ in a shaking incubator (Vision Science Co. Ltd., Korea) at $220 \mathrm{rpm}$. After incubation, the bacterial cells were harvested by centrifugation at $4400 \mathrm{~g}$ for $20 \mathrm{~min}$. The resulting pellets were resuspended in $40 \mathrm{~mL}$ of binding buffer $(20 \mathrm{mM}$ Tris- $\mathrm{HCl}, 8 \mathrm{M}$ urea, $500 \mathrm{mM}$ $\mathrm{NaCl}, 20 \mathrm{mM}$ imidazole (Sigma, USA) [pH 8.0], and $1 \mathrm{mM} \beta$-mercaptoethanol (Sigma, USA) and sonicated at $10000 \mathrm{~Hz}$ in ice water (60\% pulse, $20 \mathrm{~s}$ pulse/50 s steps, 15 cycles). Supernatants were collected after centrifugation at $4400 \times g$ for $20 \mathrm{~min}$. Recombinant proteins were collected using a His SpinTrap (GE Healthcare, UK) according to the manufacturer's protocol. Concentration of the purified recombinant proteins was measured using a BCA kit (Bio-Rad, USA). The recombinant proteins

Table 1 Primer sequences for cloning Brucella abortus genes

\begin{tabular}{|c|c|c|c|}
\hline Gene & Primer sequence $\left(5^{\prime}-3^{\prime}\right)$ & $\begin{array}{l}\text { Annealing } \\
\text { temperature }\left({ }^{\circ} \mathrm{C}\right)\end{array}$ & $\begin{array}{l}\text { Product } \\
\text { size (bp) }\end{array}$ \\
\hline \multirow[t]{2}{*}{ Outer membrane protein 28} & F: GATCGGATCCAACACTCGTGCTAGCAATTTT & 63 & 753 \\
\hline & R: GATCAAGCTTTTACTTGATTTCAAAAACGAC & & \\
\hline \multirow[t]{2}{*}{ Malate dehydrogenase } & F: AATTCGGATCCATGGCACGCAACAAGATT & 63 & 963 \\
\hline & R: AGGCGTCGACTTATTTCAGCGACGGAGC & & \\
\hline \multirow[t]{2}{*}{ Elongation factor } & F: AATTCGAATTCATGAGCATTTCCGCATCT & 63 & 918 \\
\hline & R: AGGCCTGCAGTCAGCCCTTGGCGGCTGCGGC & & \\
\hline \multirow[t]{2}{*}{ Arginase } & F: AGCGCGGATCCATGCATTGTAAGATTCTG & 63 & 918 \\
\hline & R: AGGCCTGCAGTCAATAGCTGATGGTCGG & & \\
\hline \multirow[t]{2}{*}{ Metal-dependent hydrolase } & F: AGCGCGGATCCATGCATTGTAAGATTCTG & 63 & 711 \\
\hline & R: AGCGCTGCAGTTAAGCTTGGAAGCTGTG & & \\
\hline
\end{tabular}


were analyzed by SDS-PAGE and Western blotting with an anti-His antibody (April Bio Co. Ltd., Korea). LPS contamination in the purified proteins was confirmed by endotoxin assay kit (Toxin Sensor ${ }^{\mathrm{TM}}$ Chromogenic LAL endotoxin Assay Kit, GenScript).

\section{bPBMC isolation and culturing}

Blood was collected into conical tubes (Nunc, USA) containing heparin from the jugular vein of clinically healthy Korean native cattle. The cattle were naïve to $B$. abortus exposure. The blood was overlaid onto $15 \mathrm{~mL}$ of Histopaque 1077 (Sigma, USA) in a $50 \mathrm{~mL}$ conical tube and centrifuged $400 \times g$ for $30 \mathrm{~min}$. Next, bPBMC were collected and washed three times with RPMI 1640 medium (Gibco, USA) containing $10 \%$ fetal bovine serum (Gibco, USA). The bPBMC concentration was adjusted to $5 \times 10^{6}$ cells $/ \mathrm{mL}$ and the cells were cultured in a 6 -well plate with RPMI 1640 medium containing 10\% FBS for $8 \mathrm{~h}$ at $37{ }^{\circ} \mathrm{C}$ in a $5 \% \mathrm{CO}_{2}$ atmosphere. After incubation, the bPBMC were stimulated with 5 or $10 \mu \mathrm{g} / \mathrm{mL}$ of the five different recombinant proteins for the indicated time intervals in the figures. LPS was removed by treatment with polymyxin $\mathrm{B}(10 \mu \mathrm{g} / \mathrm{mL})$ before stimulation with the proteins. Concanavalin A (ConA, $1 \mu \mathrm{g} / \mathrm{mL})$ was used as a positive control. All animal procedures were carried out according to the guidelines of the Institutional Animal Care and Use Committee (IACUC) of the Animal and Plant Quarantine Agency (South Korea). The study protocol was approved by the Seoul National University Institutional Animal Care and Use Committee (SNUIACUC: SNU-130916-3).

\section{Purification of total RNA from $b P B M C$}

Total RNA was isolated from the bPBMC using an RNeasy mini kit (Qiagen, Germany) according to the manufacturer's protocol. Before reverse transcription of the RNA using a QuantiTect ${ }^{\circledR}$ Reverse Transcription Kit (Qiagen, Germany) was performed, genomic DNA was eliminated with $2 \mu \mathrm{L}$ of gDNA wipeout buffer $(7 \times), 11$ $\mu \mathrm{L}$ of RNase-free water, and $1 \mu \mathrm{g}$ of template RNA. After incubating the mixture at $42{ }^{\circ} \mathrm{C}$ for $2 \mathrm{~min}$, reverse transcription was carried out with $1 \mu \mathrm{L}$ of quantiscript reverse transcriptase, $4 \mu \mathrm{L}$ of quantiscript RT buffer $(5 \times), 1 \mu \mathrm{L}$ of reverse transcription primer mix, and $14 \mu \mathrm{L}$ of cDNA generated by incubation at $42{ }^{\circ} \mathrm{C}$ for $15 \mathrm{~min}$. Quantiscript reverse transcriptase was inactivated by incubation at $95^{\circ} \mathrm{C}$ for $15 \mathrm{~min}$. The reaction products were used to analyze gene expression with real-time PCR.

\section{Analysis of cytokine and apoptosis-associated genes by real-time PCR}

Real-time PCR was carried out using the cDNA products after completing reverse transcription-PCR. A
Rotor-Gene SYBR Green PCR Kit (Qiagen, Germany) was used with a two-step cycling protocol including denaturation at $95{ }^{\circ} \mathrm{C}$ and a combined annealing/extension step dependent upon the primer $\mathrm{T}_{\mathrm{m}}$ value according to the manufacturer's protocol. The reaction mixture contained $10 \mu \mathrm{L}$ of $2 \times$ Rotor-Gene SYBR Green PCR Master Mix, $2 \mu \mathrm{L}$ of the primers, $2 \mu \mathrm{L}$ of template DNA or cDNA, and $6 \mu \mathrm{L}$ of RNase-free water. The real-time PCR conditions were as follows: initial denaturation at $95{ }^{\circ} \mathrm{C}$ for $5 \mathrm{~min}$ followed by 50 cycles of $95^{\circ} \mathrm{C}$ for $20 \mathrm{~s}$ and annealing at $55^{\circ} \mathrm{C}$ or $60^{\circ} \mathrm{C}$ for $10 \mathrm{~s}$. The expression of each gene was normalized relative to the expression of $\beta$-actin. Genes encoding inducible nitric oxide synthase (iNOS), IL-1 $\beta$, IL-4, Il-6, IL-12p40, interferon (IFN)- $\gamma$, and TNF- $\alpha$ were analyzed. Three apoptosis-related genes, $\mathrm{Bcl}$-2-associated $\mathrm{X}$ protein (Bax), B cell lymphoma 2 (Bcl-2), and Toll-like receptor-4 (TLR4), were also analyzed. Sequences of the primers and probes used in this real-time PCR are presented in Table 2.

\section{Statistical analysis}

Data are reported as the mean \pm standard error of the mean (SEM.) of three or more independent experiments. Statistically significant was determined by the Student $t$ test using statistical package for social science (SPSS) software version 21 . Differences were considered to be significant if a $p$ value was $<0.05$.

\section{Results}

Genes encoding five different cellular proteins of $B$. abortus (OMP28, mdh, tsf, rocF, and 0628) were cloned, sequenced, and expressed in E. coli. The expressed proteins were purified and analyzed by SDS-PAGE and Western blotting using an anti-His antibody (Figure 1). Generally, treatment with each recombinant protein induced different patterns of cytokine expression depending on stimulation time and dose. However, the expression of apoptosis-related genes was not greatly affected by stimulation with the recombinant proteins.

Induction of iNOS gene expression was up-regulated at 12 or $24 \mathrm{~h}$ after stimulation of bPBMC with $10 \mu \mathrm{g}$ of OMP28, mdh, tsf, and rocF proteins $(p<0.01)$ while there was no significant change in the gene expression with $5 \mu \mathrm{g}$ of all proteins (Figure 2). IL- $1 \beta$ gene expression was significantly down-regulated dose and timedependently after stimulation with $5 \mu \mathrm{g}$ and $10 \mu \mathrm{g}$ of all proteins in the cells $(p<0.05, p<0.01)$ (Figure 3). In case of IL-4, induction of significant gene expression was observed in the bPBMC stimulated with only $5 \mu \mathrm{g}$ of rocF protein $(p<0.05)$ even though $10 \mu \mathrm{g}$ of tsf and 0628 proteins induced the gene expression in the cells (Figure 4). Expression of IL-6 gene was highly induced time and dose-dependently with all proteins $(p<0.01)$ 
Table 2 Primer sets used for real-time PCR

\begin{tabular}{|c|c|c|c|c|}
\hline Gene & Primer sequence $\left(5^{\prime}-3^{\prime}\right)$ & $\begin{array}{l}\text { Annealing } \\
\text { temperature }\left({ }^{\circ} \mathrm{C}\right)\end{array}$ & Product size (bp) & Reference \\
\hline \multirow[t]{2}{*}{ iNOS } & F: AGCGGAGTGACTTTCCAAGA & 55 & 97 & {$[40]$} \\
\hline & R:TTTTGGGGTTCATGATGGAT & & & \\
\hline \multirow[t]{2}{*}{$I L-1 \beta$} & F: ACCTTCATTGCCCAGGTTTCT & 55 & 120 & {$[40]$} \\
\hline & R:TGTTTGGGGTCATCAGCCTCAA & & & \\
\hline \multirow[t]{2}{*}{$\mid \mathrm{LL}-4$} & F: CAAAGAACACAACTAAGAAG & 55 & 181 & {$[40]$} \\
\hline & R: AGGTCTTTCAGCGTACTTGT & & & \\
\hline \multirow[t]{2}{*}{$\mathrm{IL}-6$} & F:TCCAGAATGAGTATGAGG & 55 & 236 & {$[40]$} \\
\hline & R: CATCCGAATAGCTCTCAG & & & \\
\hline \multirow[t]{2}{*}{ IL-12p40 } & F: AACCTGCAACTGAGACCATT & 55 & 186 & {$[40]$} \\
\hline & R: ATCCTTGTGGCATGTGACTT & & & \\
\hline \multirow[t]{2}{*}{$\mathrm{IFN}-\gamma$} & F: ATAACCAGGTCATTCAAAGG & 55 & 218 & {$[40]$} \\
\hline & R: ATTCTGACTTCTCTTCCGCT & & & \\
\hline \multirow[t]{2}{*}{ TNF-a } & F:TAACAAGCCAGTAGCCCACG & 55 & 277 & {$[40]$} \\
\hline & R: GCAAGGGCTCTTGATGGCAGA & & & \\
\hline \multirow[t]{2}{*}{ Bax } & F:TCTCCCCGAGAGGTCTTTTTT & 55 & 151 & {$[41]$} \\
\hline & R:TGATGGTCCTGATCAACTCG & & & \\
\hline \multirow[t]{2}{*}{$\mathrm{BCl}-2$} & F: ATGTGTGTGGAGAGCGTCAA & 55 & 146 & {$[41]$} \\
\hline & R: CTAGGGCCATACAGCTCCAC & & & \\
\hline \multirow[t]{2}{*}{ TLR4 } & F:TGACATCTTCACAGAACTGACTA & 55 & 164 & This study \\
\hline & R: GGAGTGGTTCATAAAGAAATGTA & & & \\
\hline \multirow[t]{2}{*}{$\beta$-actin } & F: CGCACCACTGGCATTGTCAT & 60 & 227 & [42] \\
\hline & R:TCCAAGGCGACGTAGCAGAG & & & \\
\hline
\end{tabular}

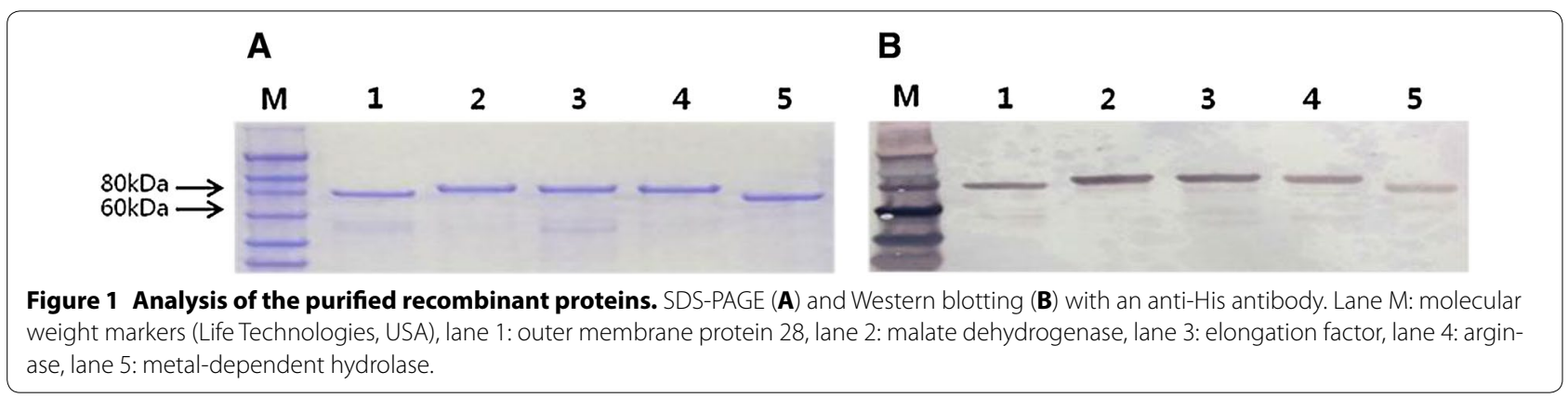

(Figure 5). mdh and rocF were the most effective inducers in the IL-6 gene expression in the bPBMC $(p<0.01)$. Also, $10 \mu \mathrm{g}$ of tsf induced the higher gene expression of IL- 6 at $12 \mathrm{~h}$ after the stimulation $(p<0.01)$. Induction of IL-12p40 gene expression was the most effective when the cells were stimulated with $5 \mu$ g of all proteins for $12 \mathrm{~h}$ $(p<0.01)$ (Figure 6). The induction was also effective with $10 \mu \mathrm{g}$ of OMP28 and 0628 recombinant proteins at 12 and/or $24 \mathrm{~h}$ after the stimulation $(p<0.01)$. IFN- $\gamma$ gene expression was significantly induced in the cells stimulated with $5 \mu \mathrm{g}$ of all proteins for $12 \mathrm{~h}(p<0.01)$ even though the significant induction was also observed with $10 \mu \mathrm{g}$ of OMP28 and 0628 proteins $(p<0.01)$ (Figure 7$)$.
After stimulation of the cells with $10 \mu \mathrm{g}$ of all proteins, TNF- $\alpha$ gene expression was significantly induced at $12 \mathrm{~h}$ and/or $24 \mathrm{~h}(p<0.01)$. Five $\mu \mathrm{g}$ of the proteins could not induce the TNF- $\alpha$ gene expression except at $24 \mathrm{~h}$ with tsf protein (Figure 8). In apoptosis related gene expression, Bax, Bcl-2 and TLR4, the gene expression was mostly down-regulated in the cells stimulated with $5 \mu \mathrm{g}$ of all proteins even though $10 \mu \mathrm{g}$ of some proteins induced the gene expression at different times (Figures 9, 10, 11). The gene expression of Bax was down-regulated with $5 \mu \mathrm{g}$ of the proteins $(p<0.05)$ while $10 \mu \mathrm{g}$ of OMP28, rocF and 0628 proteins up-regulated the gene expression $(p<0.05)$ (Figure 9). However, the changes might 

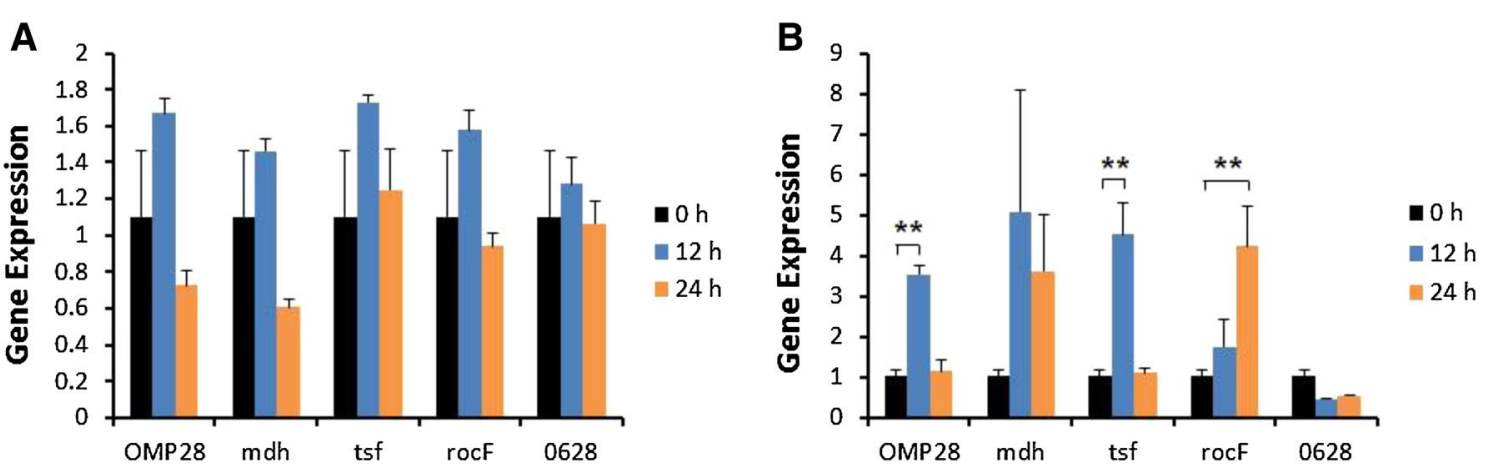

Figure 2 Gene expression of inducible nitric oxide synthease (iNOS) in bovine PBMC. Bovine PBMC were stimulated with $5 \mu \mathrm{g}(\mathbf{A})$ and $10 \mu \mathrm{g}$ (B) of five different recombinant proteins (OMP28, mdh, tsf, rocF, and 0628) of Brucella abortus at 0, 12, and $24 \mathrm{~h}$. Gene expression was analyzed by real-time quantitative RT-PCR and normalized by the expression of $\beta$-actin.
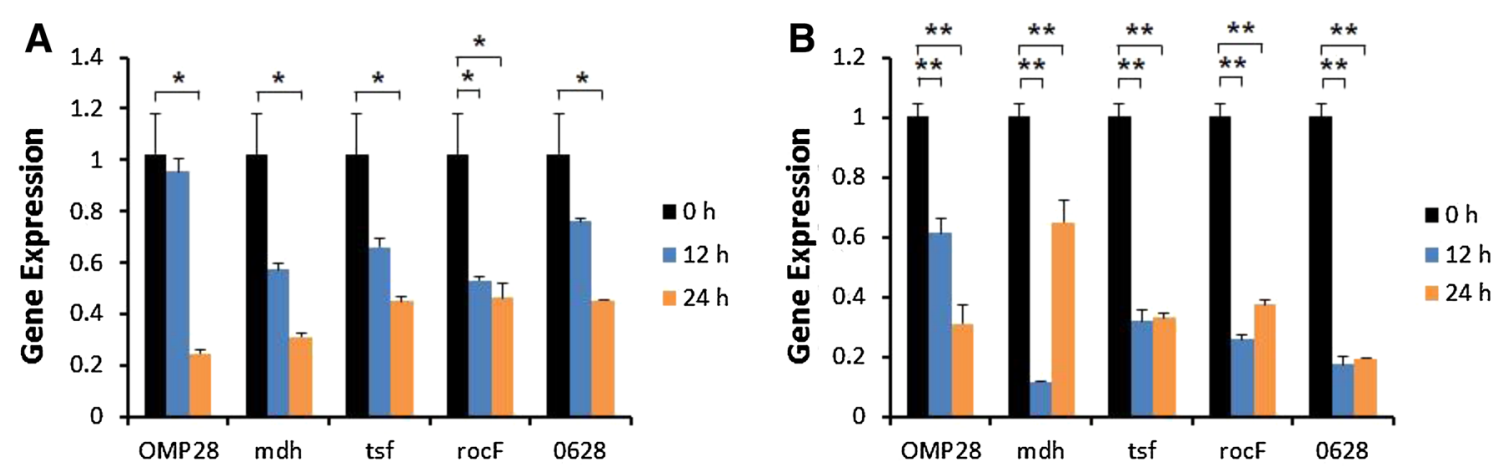

Figure 3 Gene expression of interleukin-1 $\boldsymbol{\beta}$ (IL-1 $\boldsymbol{\beta})$ in bovine PBMC. Bovine PBMC were stimulated with $5 \mu \mathrm{g}(\mathbf{A})$ and $10 \mu \mathrm{g}(\mathbf{B})$ of five different recombinant proteins (OMP28, mdh, tsf, rocF, and 0628) of Brucella abortus at 0, 12, and $24 \mathrm{~h}$. Gene expression was analyzed by real-time quantitative RT-PCR and normalized by the expression of $\beta$-actin.
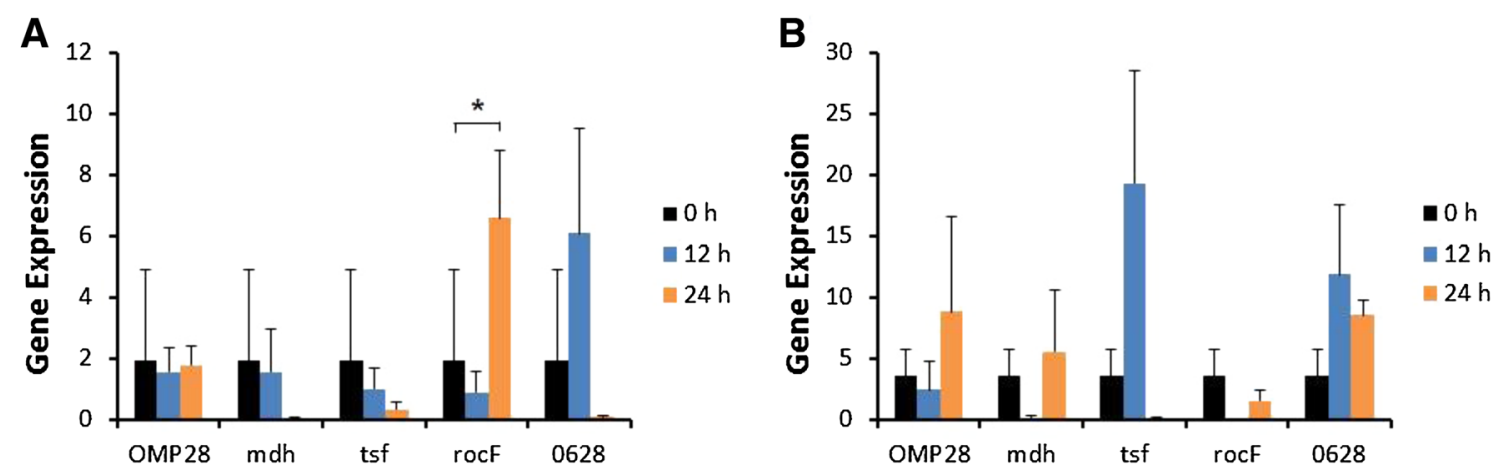

Figure 4 Gene expression of interleukin-4 (IL-4) in bovine PBMC. Bovine PBMC were stimulated with $5 \mu \mathrm{g}(\mathbf{A})$ and $10 \mu \mathrm{g}$ (B) of five different recombinant proteins (OMP28, mdh, tsf, rocF, and 0628) of Brucella abortus at 0, 12, and $24 \mathrm{~h}$. Gene expression was analyzed by real-time quantitative RT-PCR and normalized by the expression of $\beta$-actin.

not be effective even though there was significant difference. $\mathrm{Bcl}-2$ gene expression was effectively up-regulated with $10 \mu \mathrm{g}$ of $\mathrm{mdh}$ in $24 \mathrm{~h}$ stimulation $(p<0.01)$. There were no meaningful changes in the gene expression of Bcl-2 (Figure 10). TLR4 gene expression was significantly down-regulated when the cells stimulated with $5 \mu \mathrm{g}$ of 

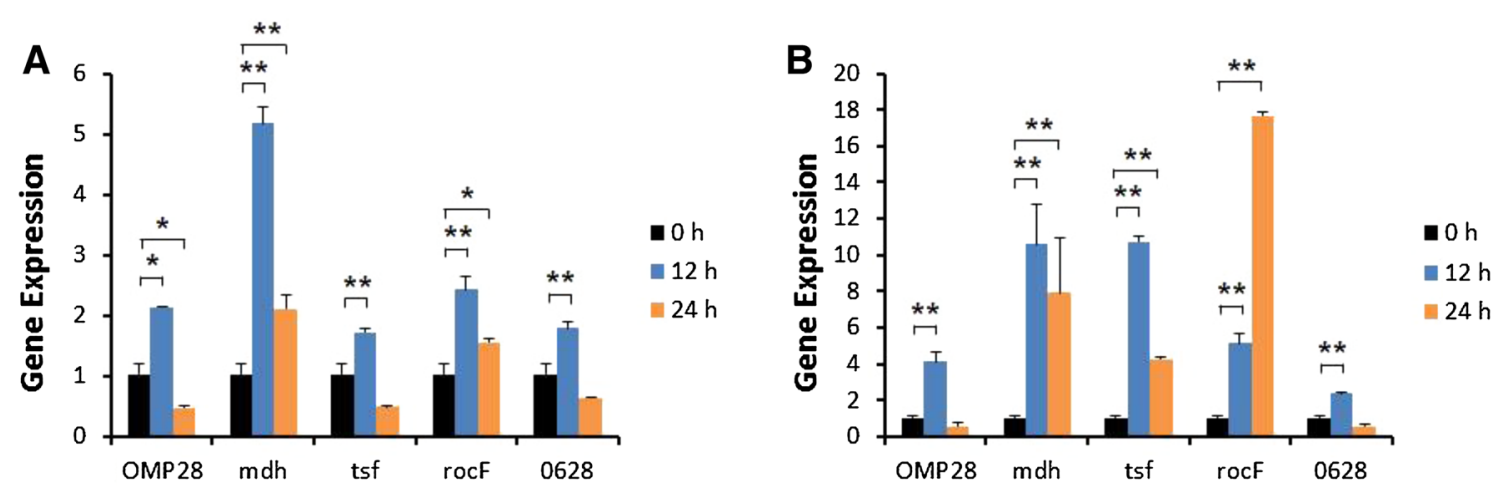

Figure 5 Gene expression of interleukin-6 (IL-6) in bovine PBMC. Bovine PBMC were stimulated with $5 \mu \mathrm{g}(\mathbf{A})$ and $10 \mu \mathrm{g}(\mathbf{B})$ of five different recombinant proteins (OMP28, mdh, tsf, rocF, and 0628) of Brucella abortus at 0, 12, and $24 \mathrm{~h}$. Gene expression was analyzed by real-time quantitative RT-PCR and normalized by the expression of $\beta$-actin.
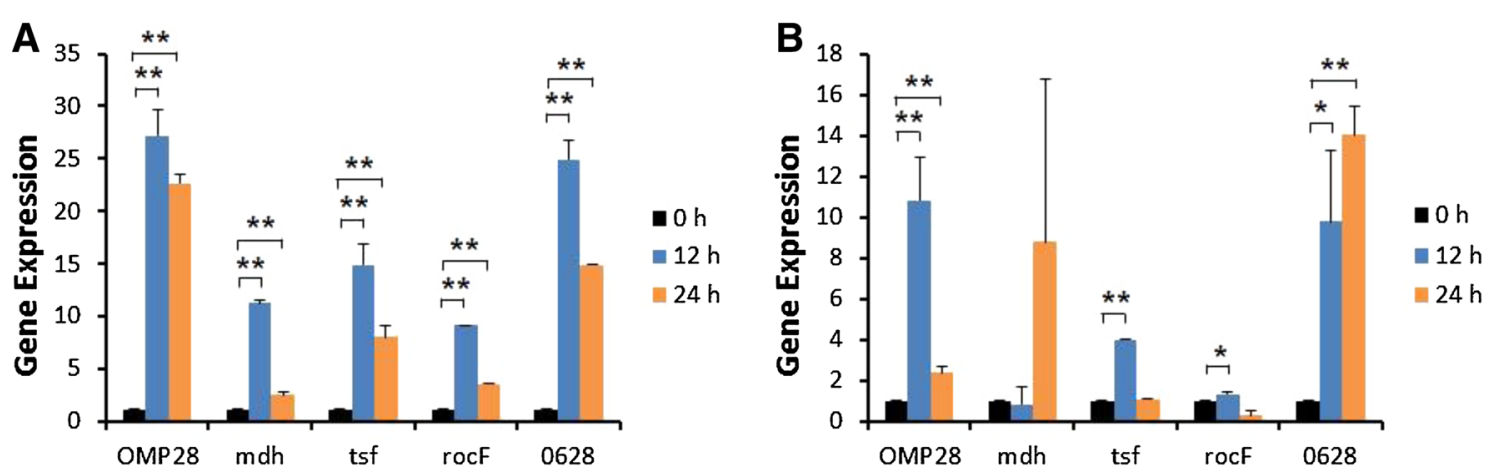

Figure 6 Gene expression of interleukin-12 p40 (IL-12p40) in bovine PBMC. Bovine PBMC were stimulated with $5 \mu \mathrm{g}(\mathbf{A})$ and $10 \mu \mathrm{g}(\mathbf{B})$ of five different recombinant proteins (OMP28, mdh, tsf, rocF, and 0628) of Brucella abortus at 0, 12, and $24 \mathrm{~h}$. Gene expression was analyzed by realtime quantitative RT-PCR and normalized by the expression of $\beta$-actin.
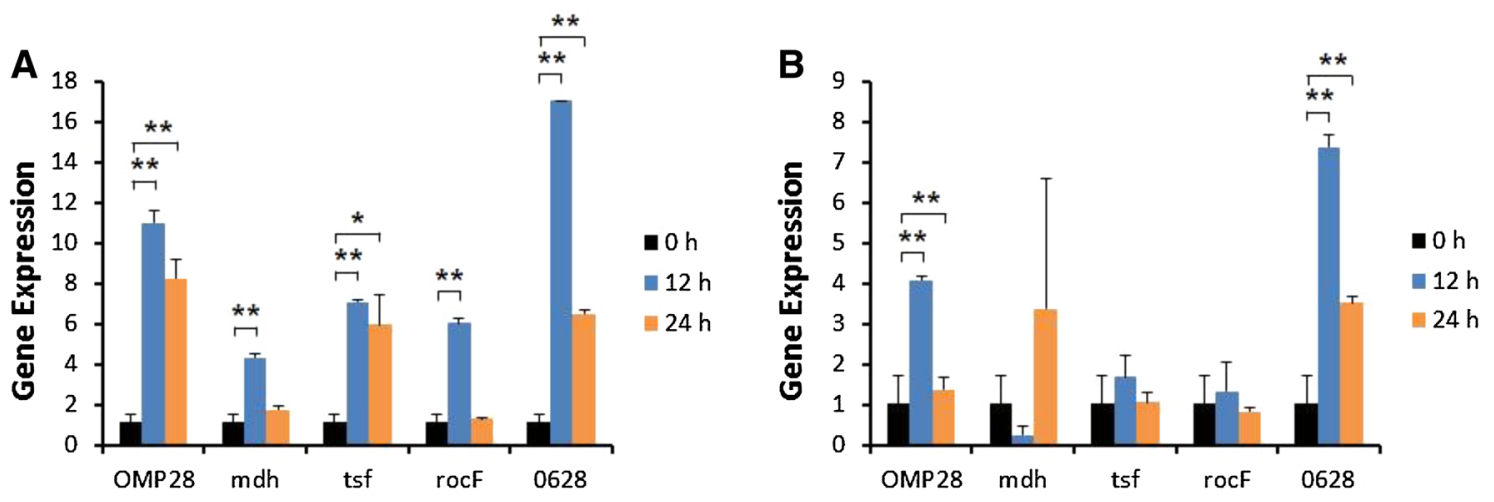

Figure 7 Gene expression of interferon- $\boldsymbol{\gamma}$ (IFN- $\boldsymbol{\gamma})$ in bovine PBMC. Bovine PBMC were stimulated with $5 \mu \mathrm{g}(\mathbf{A})$ and $10 \mu \mathrm{g}(\mathbf{B})$ of five different recombinant proteins (OMP28, mdh, tsf, rocF, and 0628) of Brucella abortus at 0, 12, and $24 \mathrm{~h}$. Gene expression was analyzed by real-time quantitative RT-PCR and normalized by the expression of $\beta$-actin.

all proteins $(p<0.05)$ while $10 \mu \mathrm{g}$ of mdh and rocF proteins induced higher gene expression of TLR4 $(p<0.05)$ (Figure 11).
In summary, the production of iNOS, IL-4 and TNF- $\alpha$ was not effectively induced in bPBMC by stimulation with the recombinant proteins even though some 

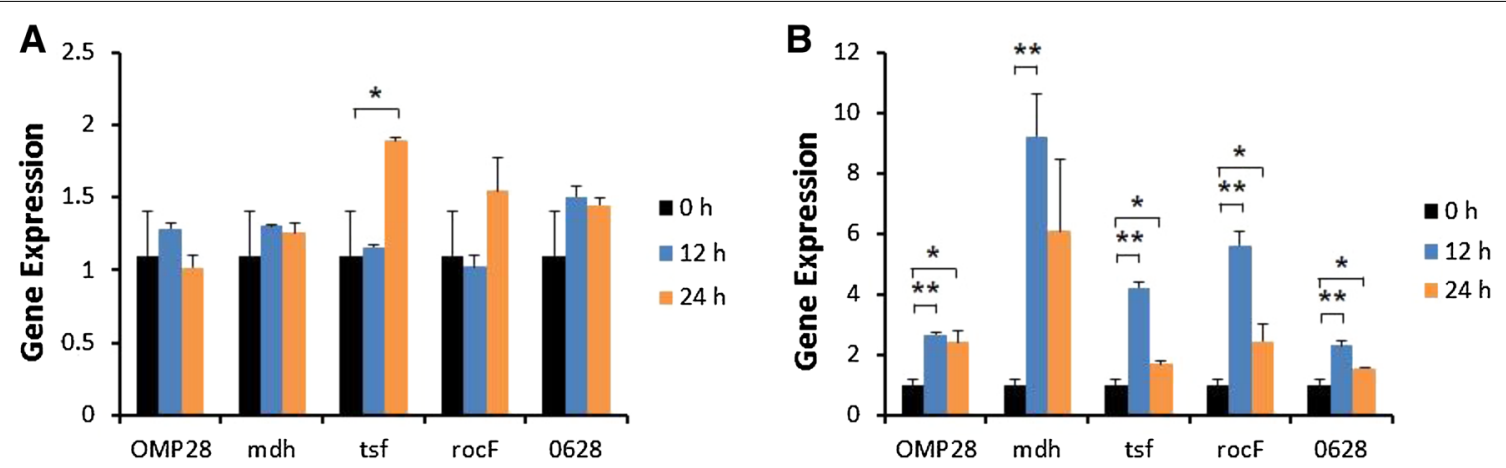

Figure 8 Gene expression of tumor necrosis factor-a (TNF-a) in bovine PBMC. Bovine PBMC were stimulated with $5 \mu \mathrm{g}(\mathbf{A})$ and $10 \mu \mathrm{g}(\mathbf{B})$ of five different recombinant proteins (OMP28, mdh, tsf, rocF, and 0628) of Brucella abortus at 0, 12, and $24 \mathrm{~h}$. Gene expression was analyzed by realtime quantitative RT-PCR and normalized by the expression of $\beta$-actin.
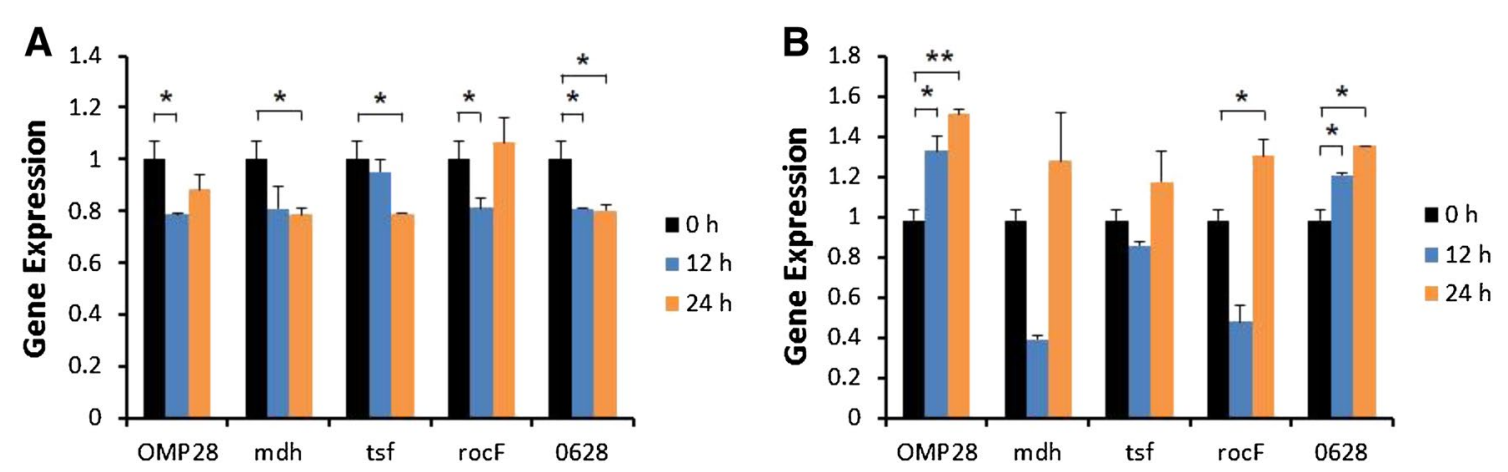

Figure 9 Gene expression of Bax in bovine PBMC. Bovine PBMC were stimulated with $5 \mu \mathrm{g}(\mathbf{A})$ and $10 \mu \mathrm{g}(\mathbf{B})$ of five different recombinant proteins (OMP28, mdh, tsf, rocF, and 0628) of Brucella abortus at 0, 12, and $24 \mathrm{~h}$. Gene expression was analyzed by real-time quantitative RT-PCR and normalized by the expression of $\beta$-actin.

induction was observed at certain times by treatment with $10 \mu \mathrm{g}$ of OMP28, tsf, and rocF. IL-1 $\beta$ gene expression was down-regulated in dose and time-dependent manner in the stimulation of cells with all proteins. IL-6, IL-12p40 and IFN- $\gamma$ gene expression was effectively induced in the cells stimulated with all proteins, especially $5 \mu \mathrm{g}$ of the proteins. The expression of a gene associated with apoptosis in bPBMC was not induced by exposure to $5 \mu \mathrm{g}$ of the recombinant proteins. However, expression of the apoptotic genes was induced with different expression profiles at 12 or 24 h by stimulation with $10 \mu \mathrm{g}$ of some proteins.

\section{Discussion}

Brucellosis is a re-emerging zoonosis that has regained attention of the scientific community because pathogenesis of this disease in humans and animals has significantly evolved $[3,28]$. However, the overall burden of the disease remains underestimated and has not been well studied. Eradication of brucellosis in animals is important for prevention of this disease in humans and requires optimal diagnosis along with vaccination [29]. The cellular proteins of $B$. abortus have received increased attention in the development of diagnostic techniques and vaccines given the important roles of these proteins in the early stage of infection [23]. In addition, the information will help to reveal mechanisms underlying the pathogenesis of Brucella infection.

Brucella is able to infect macrophages, and persist and replicate in the intracellular environment [30]. Identifying bacterial proteins that are necessary for intracellular survival of Brucella may provide new insights into mechanisms associated with pathogenesis and immune protection along with candidate antigens for diagnosis and vaccines [31-33]. Although several immunogenic proteins of B. abortus have been identified [24-27], roles of these proteins still remain unclear. Based on recently acquired knowledge, five different cellular proteins with unknown potential in the induction of immune responses were selected for analysis in this study and effects of the proteins on $\mathrm{BPBMC}$ were investigated. 

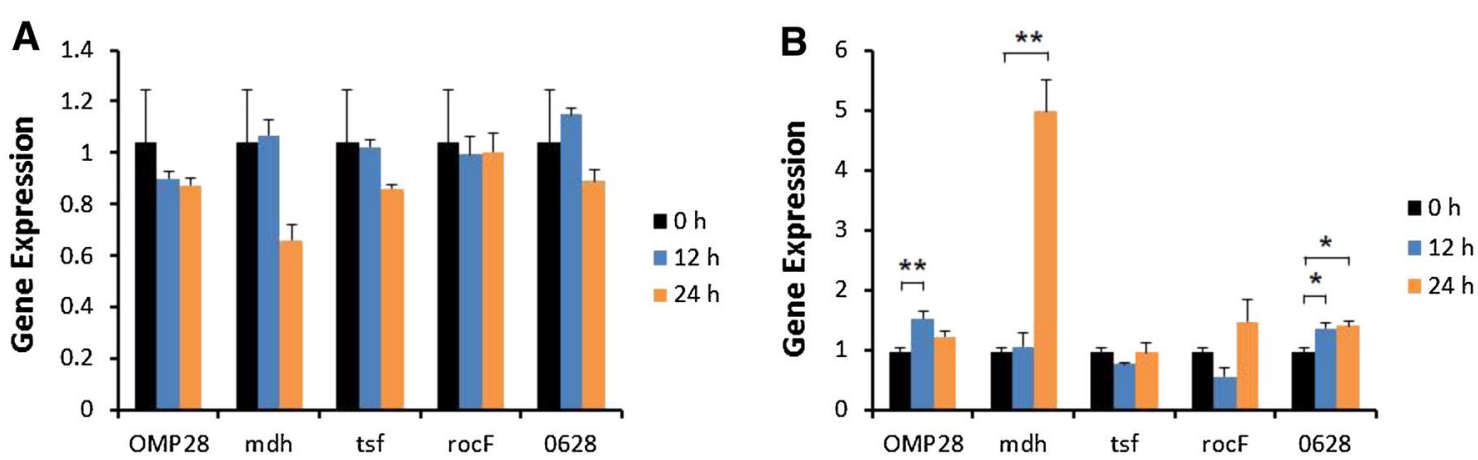

Figure 10 Gene expression of Bcl-2 in bovine PBMC. Bovine PBMC were stimulated with $5 \mu \mathrm{g}(\mathbf{A})$ and $10 \mu \mathrm{\mu g}(\mathbf{B})$ of five different recombinant proteins (OMP28, mdh, tsf, rocF, and 0628) of Brucella abortus at 0, 12, and $24 \mathrm{~h}$. Gene expression was analyzed by real-time quantitative RT-PCR and normalized by the expression of $\beta$-actin.
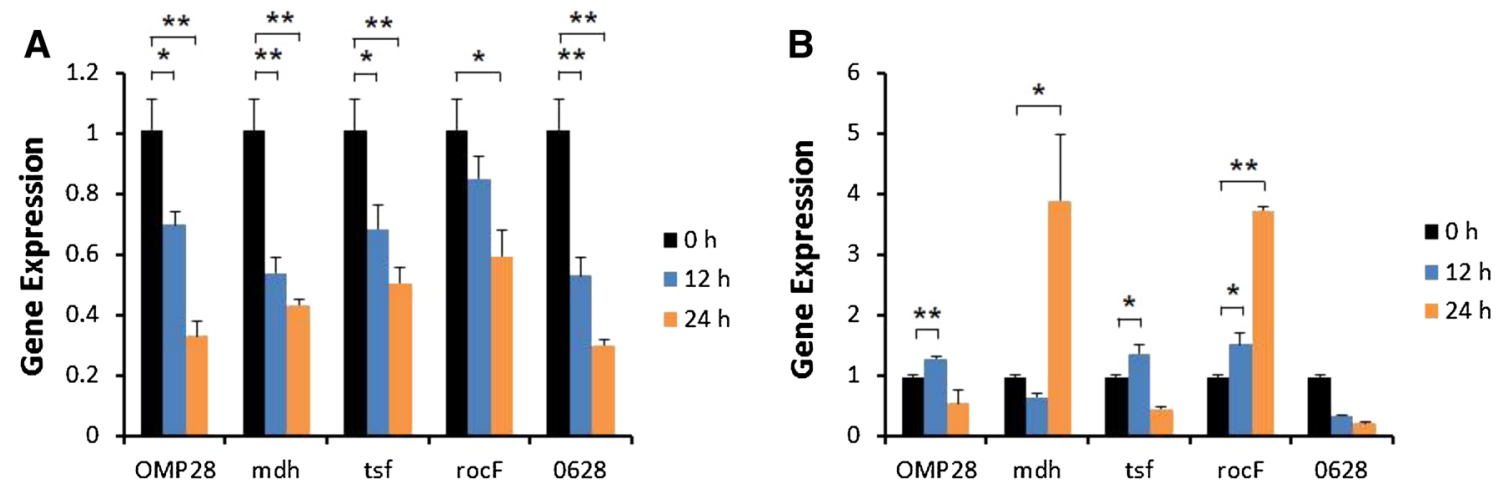

Figure 11 Gene expression of Toll-like receptor 4 (TLR4) in bovine PBMC. Bovine PBMC were stimulated with $5 \mu \mathrm{g}(\mathbf{A})$ and $10 \mu \mathrm{g}(\mathbf{B})$ of five different recombinant proteins (OMP28, mdh, tsf, rocF, and 0628) of Brucella abortus at 0, 12, and $24 \mathrm{~h}$. Gene expression was analyzed by real-time quantitative RT-PCR and normalized by the expression of $\beta$-actin.

To evaluate the potential of five protein antigens as diagnostic antigens, underlying mechanisms of the proteins in PBMC were investigated. Therefore, five genes were cloned, and the recombinant proteins were expressed and purified. After stimulation of bPBMC with the proteins, the expression of cytokines and apoptosis-related genes were analyzed by real-time reverse transcription-PCR. Most of the proteins induced the expression of IL-6, IL-12p40 and IFN- $\gamma$ in a time- and dose-dependent manner. This result concurs with finding from a previous study showing that high amounts of IFN- $\gamma$, IL-12, and IL- 6 are produced by splenocytes of mice vaccinated with chaperone protein DnaK [31]. In vivo-induced antigen technology (IVIAT) using elk (Cervus elaphus) revealed that mdh is a predictor of natural infection [34]. Mdh is commonly expressed during infection in cattle and elk, and is not only an immunogenic protein but also promotes bacterial pathogenesis as a new virulence factor $[34,35]$. These data are similar to our results showing the effect of mdh on cytokine production.

The $B$. abortus efp mutant has slower growth in complex media and higher sensitivity to detergents [36]. The efp gene is also required for internalization in nonprofessional macrophages, HeLa cells [36]. However, the gene does not appear to be associated with virulence in professional macrophages, J774 macrophage-like cells, or mice [36].

Immune responses rely to a great extent on the recognition of foreign antigens by toll-like receptors (TLR). These receptors detect different pathogen-associated molecular patterns (PAMP), and trigger the activation of myeloid differentiation primary response gene 88 (MyD88)- and TIR-domain-containing adaptor-inducing interferon- $\beta$ (TRIF)-dependent signaling pathways. This in turn leads to a wide range of cellular responses including the secretion of proinflammatory cytokines, chemokines, and type I interferons [37]. In our study, 
gene expression of TLR4 was down-regulated up to $24 \mathrm{~h}$ and up-regulated in the stimulation with the proteins. Previous studies on the TLR4 expression showed down-regulation of TLR4 expression up to $24 \mathrm{~h}$ and upregulation of the expression after $24 \mathrm{~h}$ in the macrophage cells stimulated B. abortus or LPS of the bacterium [38, 39]. This phenomenon was similar with our results with bPBMC.

These results suggest that the recombinant proteins might induce proper immune responses without adverse effects (such as apoptosis) in the bPBMC. Gene expression of iNOS, TNF- $\alpha$, and IL- $1 \beta$ was not effective in the cells by stimulation with the proteins. On the contrary, gene expression of IL-6, IL-12p40, and IFN- $\gamma$ was significantly increased with the recombinant proteins. These results indicate that the adaptive immune systems are effectively activated by the proteins in bPBMC. In conclusion, the five recombinant $B$. abortus proteins examined in this study appear to induce effective adaptive immune responses in both humoral and cellular immunity without induction of inflammatory reaction.

\section{Competing interests}

The authors declare that they have no competing interests.

\section{Author details \\ ${ }^{1}$ Department of Infectious Diseases, College of Veterinary Medicine, Seoul National University, Seoul 08826, South Korea. ${ }^{2}$ College of Veterinary Medi- cine, Gyeongsang National University, Jinju 52828, South Korea. ${ }^{3}$ Institute of Green-Bio Science and Technology, Seoul National University, Pyeo- ngchang 25354, South Korea.}

\section{Authors' contributions}

$\mathrm{YBI}, \mathrm{MJ}$ and $\mathrm{HSY}$ planned and conceived the experiments. YBI, MJ and MKS isolated bovine PBMC and carried out other laboratory works. YBI, MKS and HSY analyzed data and designed the figures. HSY and SK wrote the manuscript. All authors read and approved the final manuscript.

\section{Acknowledgements}

This study was funded by the Ministry of Agriculture, Food and Rural Affairs (iPET112012-3), MSIP (no. 2014R1A2A2A01007291), BK21 PLUS and Research Institute for Veterinary Science, Seoul National University (Seoul, South Korea).

Received: 23 May 2015 Accepted: 12 January 2016

Published online: 11 February 2016

\section{References}

1. Corbel MJ (1997) Brucellosis: an overview. Emerg Infect Dis 3:213-221

2. Sung KY, Yoo HS (2014) Host immune responses during Brucella infection: a brief review. J Prev Vet Med 38:26-34

3. Seleem MN, Boyle SM, Sriranganathan N (2010) Brucellosis: a re-emerging zoonosis. Vet Microbiol 140:392-398

4. Young EJ (1995) An overview of human brucellosis. Clin Infect Dis 21:283-289

5. Nielsen K, Yu WL (2010) Serological diagnosis of brucellosis. Prilozi 31:65-89

6. Moreno E, Jones LM, Berman DT (1984) Immunochemical characterization of rough Brucella lipopolysaccharides. Infect Immun 43:779-782

7. Jiménez de Bagüés MP, Marín CM, Blasco JM, Moriyón I, Gamazo C (1992) An ELISA with Brucella lipopolysaccharide antigen for the diagnosis of B. melitensis infection in sheep and for the evaluation of serological responses following subcutaneous or conjunctival $B$. melitensis strain Rev 1 vaccination. Vet Microbiol 30:233-241

8. Gall D, Nielsen K, Nicola A, Renteria T (2008) A proficiency testing method for detecting antibodies against Brucella abortus in quantitative and qualitative serological tests. Res Sci Tech 27:819-828

9. McGiven JA (2013) New development in the immunodiagnosis of brucellosis in livestock and wildlife. Res Sci Tech 32:163-176

10. Corbel MJ (1979) The relationship between the protective and crossreacting antigens of Brucella spp., Yersinia enterocolitica 0:9 and Salmonella serotypes of Kauffmann-White group N. Contrib Microbiol Immunol 5:50-63

11. Nielsen K, Smith P, Widdison J, Gall D, Kelly L, Kelly W, Nicoletti P (2004) Serological relationship between cattle exposed to Brucella abortus, Yersinia enterocolitica O:9 and Escherichia coli O157:H7. Vet Microbiol 100:25-30

12. Cheers C (1984) Pathogenesis and cellular immunity in experimental murine brucellosis. Dev Biol Stand 56:237-246

13. Dornand J, Gross A, Lafont V, Liautard J, Oliaro J, Liautard JP (2002) The innate immune response against Brucella in humans. Vet Microbiol 90:383-394

14. Golding B, Scott DE, Scharf O, Huang LY, Zaitseva M, Lapham C, Eller N, Golding H (2001) Immunity and protection against Brucella abortus. Microbes Infect 3:43-48

15. Li JY, Liu Y, Gao XX, Gao X, Cai H (2014) TLR2 and TLR4 signaling pathways are required for recombinant Brucella abortus BCSP31-induced cytokine production, functional upregulation of mouse macrophages, and the Th1 immune response in vivo and in vitro. Cell Mol Immunol 11:478-494

16. Barquero-Calvo E, Chaves-Olarte E, Weiss DS, Guzman-Verri C, ChaconDiaz C, Rucavado A, Moriyon I, Moreno E (2007) Brucella abortus uses a stealthy strategy to avoid activation of the innate immune system during the onset of infection. PLoS One 2:e631

17. Paixao TA, Roux CM, Den Hartigh AB, Sankaran-Walters S, Dandekar $S$, Santos RL, Tsolis RM (2009) Establishment of systemic Brucella melitensis infection through the digestive tract requires urease, the type IV secretion system, and lipopolysaccharide. Infect Immun 77:4197-4208

18. Poester FP, Samartino LE, Santos RL (2013) Pathogenesis and pathobiology of brucellosis in livestock. Rev Sci Tech 32:105-115

19. Huang LY, Aliberti J, Leifer CA, Segal DM, Sher A, Golenbock DT, Golding B (2003) Heat-killed Brucella abortus induces TNF and IL-12p40 by distinct MyD88-dependent pathways: TNF, unlike IL-12p40 secretion, is Toll-like receptors dependent. J Immunol 171:1441-1446

20. Zaitseva M, Golding H, Manischewitz J, Webb D, Golding B (1996) Brucella abortus as a potential vaccine candidate: induction of interleukin-12 secretion and enhanced B7.1 and B7.2 and intercellular adhesion molecule 1 surface expression in elutriated human monocytes stimulated by heat-inactivated B. abortus. Infect Immun 64:3109-3117

21. Zhan Y, Cheers C (1995) Differential induction of macrophage-derived cytokines by live and dead intracellular bacteria in vitro. Infect Immun 63:720-723

22. Zhan Y, Kelso A, Cheers C (1993) Cytokine production in the murine response to Brucella infection or immunization with antigenic extracts. Immunology 80:458-464

23. Cha SB, Rayamajhi N, Kang ML, Lee WJ, Shin MK, Yoo HS (2010) Comparative study of gamma interferon production in mice immunized with outer membrane proteins and whole bacteria of Brucella abortus. Jpn J Infect Dis 63:49-51

24. Kim JY, Sung SR, Lee KC, Lee HK, Kang SI, Lee JJ, Jung SC, Park YH, Her M (2014) Immunoproteomics of Brucella abortus RB51 as candidate antigens in serological diagnosis of brucellosis. Vet Immunol Immunopathol 160:218-224

25. Ko KY, Kim JW, Her M, Kang SI, Jung SC, Cho DH, Kim JY (2012) Immunogenic proteins of Brucella abortus to minimize cross reactions in brucellosis diagnosis. Vet Microbiol 156:374-380

26. Lee JJ, Simborio HL, Reyes AWB, Kim DG, Hop HT, Min WG, Her M, Jung SC, Yoo HS, Kim S (2014) Proteomic analyses of the time course responses of mice infected with Brucella abortus 544 reveal immunogenic antigens. FEMS Microbiol Lett 357:164-174

27. Lee JJ, Simborio HL, Reyes AWB, Kim DG, Hop HT, Min WG, Her M, Jung SC, Yoo HS, Kim S (2015) Immunoproteomic identification of immunodominant antigenic independent of the time of infection in Brucella abortus 2308-challenged cattle. Vet Res 46:17 
28. Pappas $G$ (2010) The changing Brucella ecology: novel reservoirs, new threats. Int J Antimicrob Agents 36(Suppl 1):S8-11

29. McGiven JA, Stack JA, Perrett LL, Tucker JD, Brew SD, Stubberfield E, MacMillan AP (2006) Harmonisation of European tests for serological diagnosis of Brucella infection in bovines. Rev Sci Tech 25:1039-1053

30. Hamer I, Goffin E, De Bolle X, Letesson JJ, Jadot M (2014) Replication of Brucella abortus and Brucella melitensis in fribroblast does not require Atg5-dependent macroautophagy. BMC Microbiol 14:223

31. Ghasemi A, Jeddi-Tehrani M, Mautner J, Salari MH, Zarnani AH (2014) Immunization of mice with a novel recombinant molecular chaperon confers protection against Brucella melitensis infection. Vaccine 32:6659-6666

32. Goldbaum FA, Leoni J, Wallach JC, Fossati CA (1993) Characterization of an 18-kilodalton Brucella cytoplasmic protein which appears to be a serological marker of active infection of both human and bovine brucellosis. J Clin Microbiol 31:2141-2145

33. Baldi PC, Giambartolomei GH, Goldbaum FA, Abdón LF, Velikovsky CA, Kittelberger R, Fossati CA (1996) Humoral immune response against lipopolysaccharide and cytoplasmic proteins of Brucella abortus in cattle vaccinated with $B$. abortus S19 or experimentally infected with Yersinia enterocolitica serotype 0:9. Clin Diagn Lab Immunol 3:472-476

34. Lowry JE, Goodridge L, Vernati G, Fluegel AM, Edwards WH, Andrews GP (2010) Identification of Brucella abortus genes in elk (Cervus elaphus) using in vivo-induced antigen technology (IVIAT) reveals novel markers of infection. Vet Microbiol 14:367-372

35. Han X, Tong Y, Tian M, Sun X, Wang S, Ding C, Yu S (2014) Characterization of the immunogenicity and pathogenicity of malate dehydrogenase in Brucella abortus. World J Microbiol Biotechnol 30:2063-2070
36. lannino F, Ugalde JE, de lannino NI (2012) Brucella abortus efp gene is required for an efficient internalization in HeLa cells. Microb Pathog $52: 31-40$

37. Kawai T, Akira S (2010) The role of pattern-recognition receptors in innate immunity: update on Toll-like receptors. Nat Immunol 11:373-384

38. Weiss DS, Takeda K, Akira S, Zychlinsky A, Moreno E (2005) MyD88, but not toll-like receptors 4 and 2, is required for efficient clearance of Brucella abortus. Infect Immun 73:5137-5143

39. Nomura F, Akashi S, Sakao Y, Sato S, Kawai T, Matsumoto M, Nakanishi K, Kimoto M, Miyake K, Takeda K, Akira S (2000) Cutting edge: endotoxin tolerance in mouse peritoneal macrophages correlates with down-regulation of surface toll-like receptor 4 expression. J Immunol 164:3476-3479

40. Okagawa T, Konnai S, Mekata H, Githaka N, Suzuki S, Kariuki E, Gakuya F, Kanduma E, Shirai T, Ikebuchi R, Ikenaka Y, Ishizuka M, Murata S, Ohashi K (2012) Transcriptional profiling of inflammatory cytokine genes in African buffaloes (Syncerus caffer) infected with Theileria parva. Vet Immunol Immunopathol 148:373-379

41. Xu X, Zhang K, Huang Y, Ding L, Chen G, Zhang H, Tong D (2012) Bovine herpes virus type 1 induces apoptosis through Fas-dependent and mitochondria-controlled manner in Madin-Darby bovine kidney cells. Virol J 9:202

42. Konnai S, Usui T, Ohashi K, Onuma M (2003) The rapid quantitative analysis of bovine cytokine genes by real-time RT-PCR. Vet Microbiol 94:283-294

\section{Submit your next manuscript to BioMed Central and we will help you at every step:}

- We accept pre-submission inquiries

- Our selector tool helps you to find the most relevant journal

- We provide round the clock customer support

- Convenient online submission

- Thorough peer review

- Inclusion in PubMed and all major indexing services

- Maximum visibility for your research

Submit your manuscript at www.biomedcentral.com/submit

() Biomed Central 